\title{
TAIWAN'S ECONOMIC SECURITY IN THE CONTEXT OF CROSS-STRAIT INTERDEPENDENCE
}

\author{
Ewa Trojnar \\ Jagiellonian University in Krakow \\ Institute of Middle and Far East \\ e-mail: ewa.trojnar@uj.edu.pl
}

\begin{abstract}
Signing of the ECFA between Taiwan and China in 2010 was not widely welcomed in Taiwan. Among the many concerns about warming cross-Taiwan Strait relations, was the issue of Taiwan's economic dependence on China. Without neglecting this fact, this paper aims to assess Taiwan's current economic security based on evidence of the growing interdependence between the partners. The theoretical basis of the research consists in the recognition of neoliberal approach in international relations.
\end{abstract}

Keywords: economic security, interdependence, Taiwan, China, cross-Strait relations

\section{INTRODUCTION}

Economic cooperation between Taiwan and China is not a new phenomenon. It is rational due to their geographical proximity, the cultural similarities that simplify and facilitate contacts and the complementarity of their economies as well as evolving economic cooperation policies towards each other. Undoubtedly, these processes developed from the cross-Strait relations, which have been characterized by many twists and turns since 1949, when the Nationalist forces (Kuomintang, KMT) moved to Taiwan after their defeat in the Chinese Civil War. Although the risk of a potential conflict in the Taiwan Strait was a constant threat to Taiwan's security over the years, new factors have emerged in the $21^{\text {st }}$ century. The most important one has been growing economic interdependence. The KMT's return to power in 2008 was the turning point. Nonetheless, an alarm bell sounded amongst some Taiwanese in 2010, when economic cooperation between Taiwan and China was sealed by the Economic Cooperation Framework Agreement (ECFA). It also resonated in 2014, when Taiwanese protested against the cross-Strait Service Trade Agreement (CSSTA) with China. Taiwanese critics 
raised arguments about the impact on Taiwan's politics, democracy, and freedom resulting from the growing economic interdependence of Taiwan and China due to the KMT's policy.

The main argument of this paper is that either growing economic interdependence between Taiwan and China or isolating Taiwan's economy from cooperation with China, constitutes a security trap for Taiwan. Taiwan's economy, and therefore security per se, relies heavily on Taiwan's performance in overseas markets, and Chinese market is not only the biggest in the world, but it is also the most lucrative and overwhelmingly convenient one, due to its geographic, linguistic and cultural proximity with Taiwan.

Among the various patterns of cross-Strait cooperation, trade and investment are the ones that play an important role in Taiwan's economic security and might be analyzed as its independent variable. This study explores current trends in trade and investment, particularly between 2010 and 2014, marked by signing the ECFA in 2010 and protests against the CSSTA. Statistical data for Taiwan was collected from its official governmental sources: trade data from the Directorate General of the Customs Administration and the Ministry of Finance and investment data from the Investment Commission at the Ministry of Economic Affairs. Similarly, statistical data for China was gathered from its Ministry of Commerce and the National Bureau of Statistics of the People's Republic of China. Additionally, Taiwanese opinion polls published by the Mainland Affairs Council or the NCCU's the Election Study Center are cited.

This paper aims at assessing the Taiwan's current economic security based on evidence of the interdependence between both partners. The theoretical basis for the case study is a concept of 'asymmetrical interdependence' of Robert Keohane and Joseph S. Nye. ${ }^{1}$ It was adopted in assessing the economic security of Taiwan in terms of the sensitivity and vulnerability, which may characterize and explain cross-Strait relations. ${ }^{2}$ Consequently, Taiwan's economic security faces not only threats, but also opportunities, although accompanied by high costs.

\section{CROSS-STRAIT INTERDEPENDENCE}

Every analysis of the power distribution in cross-Strait relations suggests beyond a shadow of a doubt the dominance of China in absolute terms, both in economics and politics. China's economic potential, measured by macro indices like GDP and international trade and investments, directly show China's domi-

1 The Cross-Strait relations are however a more complex case that requires analyzing the involvement of another actor i.e. the United States, and therefore should be described as the "triangular relations" between China, Taiwan, and the United States.

2 R. O. Keohane, J. S. Nye, Power and Interdependence, Scott, Foresman and Company, Greenview 1989. 
nation over Taiwan. China has also gained a growing position in international politics and benefits from worldwide recognition based on the One-China policy framework. However, one can also easily indicate other resources and strengths on Taiwan's side, e.g., innovative economy, wealthy and developed society, and a strategic alliance with the United States. ${ }^{3}$ Only this holistic picture offers a proper framework in the analysis of the cross-Strait relations. It also explains why China is stopped from achieving its ultimate goal i.e. reunification of Taiwan with the Mainland.

Cross-Strait economic relations might be explained by the neoliberal concept of asymmetrical interdependence, where China and Taiwan depend on each other. However, it is not an equivalent relationship, and asymmetry indicates that China is the less dependent side. Taiwan, on the contrary, depends heavily on the mainland market. The core problem of this situation, posing a threat to Taiwan, results from China's ability as "less dependent to use the interdependent relationship as a source of power in bargaining over an issue and perhaps to affect other issues". ${ }^{4}$ Asymmetrical interdependence can be a source of power when analysed as either "control over resources, or the potential to affect outcomes". ${ }^{5}$ Applying Keohane's and Nye's assumptions to the cross-Strait relations case, one may conclude that changes in the relationship will be less costly to China than to Taiwan, because China has significant political resources.

As neoliberals further point out, the measurement of power "conceived in terms of control over outcomes", causes difficulties. ${ }^{6}$ Murray Scot Tanner, in his book on cross-Strait relations, faces similar challenges when adopting the asymmetrical interdependence argument. He states that both sides are "depending upon each other, although Taiwan's dependence upon the mainland is greater. Thus, even though mainland China may be highly motivated to use economic pressure against Taiwan given the issues at stake, Beijing would nevertheless have to consider carefully the economic and political costs it would suffer from such sanctions". ${ }^{7}$ The remaining question is: to what degree China might pressure Taiwan and how to assess it. Keohane and Nye define two characteristics of interdependence: sensitivity and vulnerability. The first "involves degrees of responsiveness within a policy framework - how quickly do changes in one country bring costly changes in another, and how great are the costly effects? It is measured not merely by the volume of flows across borders but also by the costly effects of changes in transactions on the societies or governments. Sensitivity interde-

3 The Taiwan Relations Act, adopted by the United States Congress in 1979, provides the legal basis for the unofficial relationship between the United States and Taiwan and is a political contribution to Taiwan's security.

4 R. O. Keohane, J. S. Nye, op. cit., p. 11.

5 Ibidem.

6 Ibidem.

7 Murray Scot Tanner, Chinese Economic Coercion Against Taiwan: A Tricky Weapon to Use, RAND Corporation, Santa Monica 2007, p. 30. 
pendence is created by interactions within a framework of policies". ${ }^{8}$ The second dimension of interdependence - vulnerability - "rests on the relative availability and costliness of the alternatives that various actors face". 9

An-chia Wu in his analysis of cross-Strait relations in the 1990s emphasizes that the asymmetry in trade between Taiwan and China makes the island both sensitive and vulnerable to policy changes in the mainland. ${ }^{10}$ Samuel C.Y. Ku argues that sensitivity and vulnerability have always been key concepts of Taiwanese foreign policy. Its limited political and economic resources created sensitivity towards changes from the mainland. China is also sensitive towards Taiwan due to its alliance with the United States. Taiwan's vulnerability, in Ku's opinion, has diminished since the 1980s together with the acceleration of the island's economy. China followed a similar pattern since the 1990s, further intensified by its grater political influence in the world. ${ }^{11}$

In order to understand the complexity of cross-Strait interdependence, two forms should be analysed, based on the general interdependence conceptualization offered by Edward D. Mansfield and Brian M. Pollins. According to the first, "there may be extensive and complex economic connections between states (yielding a high level of sensitivity interdependence), and they might not find it especially costly to replace these connections, either by expanding economic interactions with third parties or by making domestic economic adjustments (yielding a low level of vulnerability interdependence)". ${ }^{12}$ The second form requires indicating what costs Taiwan would incur if economic conditions changed or if relations with China were interrupted..$^{13}$ This paper develops the aforementioned concept to assess the costs Taiwan would incur if relations with China were interrupted. Trade and investments serve here as independent variables of Taiwan's security.

${ }^{8}$ R. O. Keohane, J. S. Nye, op.cit., p. 12.

${ }^{9}$ Ibidem, p. 13.

${ }^{10}$ An-chia Wu, Taipei-Beijing Relations: The Sovereignty Issue, (in:) Contemporary China and the Changing International Community, Bih-jaw Lin, James T. Myers (eds.), University of South California Press, Columbia 1994, p. 187-198.

${ }^{11}$ S. C. Y. Ku, The Changing Political Economy of Taiwan's and China's Relations with Southeast Asia. A Comparative Perspective, (in:) China and Southeast Asia: Global Changes and Regional Challenges, Ho Khai Leong, Samuel C. Y. Ku (eds.), Institute of Southeast Asian Studies, Singapore 2005, p. 261-262.

${ }^{12}$ E. D. Mansfield, Brian M. Pollins, Interdependence and Conflict: An Introduction, (in:) Economic Interdependence and International Conflict: New Perspectives on an Enduring Debate, Edward D. Mansfield, Brian M. Pollins (eds.), The University of Michigan Press, Ann Arbor 2003, p. 11.

${ }^{13}$ Ibidem. 


\section{TAIWAN'S SENSITIVITY AND VULNERABILITY TOWARDS CHINA: TRADE AND INVESTMENTS}

In 2014, the value of the worldwide export of Taiwan's goods and services reached US\$313 billion, what represents about $70 \%$ of its GDP. A substantial majority of Taiwan's goods are sold in Asian markets - 71\% (Table 1). Main recipients of Taiwan's exports were China 26.2\%; Hong Kong 13.6\%; the United States $11.1 \%$; Singapore 6.5\%; Japan 6.3\%; Republic of Korea 4.0\%; and Vietnam 3.1\%.

Table 1. Taiwan's export by continents in 2014 (billion US\$; \%)

\begin{tabular}{|c|r|c|}
\hline & Value & Share \\
\hline Asia & 222.31 & $71 \%$ \\
\hline North America & 37.31 & $12 \%$ \\
\hline Europe & 28.82 & $9 \%$ \\
\hline Middle and Near East & 8.07 & $3 \%$ \\
\hline Australasia & 4.50 & $1 \%$ \\
\hline Africa & 3.60 & $1 \%$ \\
\hline South America & 2.96 & $1 \%$ \\
\hline Central America & 2.80 & $1 \%$ \\
\hline Other & 3.33 & $1 \%$ \\
\hline
\end{tabular}

Source: Value of Exports \& Imports by Country, Bureau of Foreign Trade, Ministry of Economic Affairs, Republic of China (Taiwan), http://cus93.trade.gov.tw/ENGLISH/FSCE/ (access: 28.11.2015).

China and Hong Kong are the most important trading partners for Taiwan. During the last five years, the share of mainland the market amounted to $40 \%$ and should be considered as very stable (for the distribution of Taiwan's trade between China and Hong Kong see Table 2).

Table 2. Share of Taiwan's trade with China and Hong Kong (\%)

\begin{tabular}{|c|c|r|r|r|r|r|}
\hline \multicolumn{2}{|c|}{} & \multicolumn{1}{|c|}{2010} & 2011 & 2012 & 2013 & 2014 \\
\hline \multirow{2}{*}{$\begin{array}{c}\text { Taiwan's export } \\
\text { to }\end{array}$} & China & $28.0 \%$ & $27.2 \%$ & $26.8 \%$ & $26.8 \%$ & $26.2 \%$ \\
\cline { 2 - 7 } & Hong Kong & $13.8 \%$ & $13.0 \%$ & $12.6 \%$ & $12.9 \%$ & $13.6 \%$ \\
\hline \multirow{2}{*}{$\begin{array}{c}\text { Taiwan's import } \\
\text { from }\end{array}$} & China & $14.31 \%$ & $15.49 \%$ & $15.13 \%$ & $15.78 \%$ & $17.53 \%$ \\
\cline { 2 - 7 } & Hong Kong & $0.65 \%$ & $0.6 \%$ & $0.98 \%$ & $0.62 \%$ & $0.62 \%$ \\
\hline
\end{tabular}

Source: Value of Exports \& Imports...

Due to Taiwan's official ban on any contacts with China, trade was initiated in the 1980s, but the real changes occurred during the following decade. They were indirect and quite limited, but they developed rapidly, demonstrating that needs were stronger than fears. A symbolic step forward in economic relations was finalized by opening the Taiwanese islands to the coast of China's Fujian province in order to facilitate direct contacts with the nearby China, what is 
commonly referred to as establishing 'three mini links' in 2000 and 2001. Soon afterwards, additional restrictions were lifted by the ROC authorities and the admission of both Taiwan (2002) and China (2001) to the World Trade Organization further facilitated trade liberalization and economic connections. Drawing only a flourishing picture of the cross-Strait trade relations would be an exaggeration, however. Trade disputes between China and Taiwan were regular. The more interrelated Taiwan became with China, the more difficulties its authorities faced in winning the cases, which clearly depicts Taiwan's fragile position. Signing the Economic Cooperation Framework Agreement (ECFA) in mid-2010 was a major breakthrough not only in Taiwan-China trade relation, but also in the cross-Strait relations per se. The ECFA opened new channels for trade with China and therefore facilitated Taiwan's growth, enabling it to use its assets in the mainland. Apparently, the potential of China's market could discourage alternative trade directions and it would not be surprising, if Taiwan's trade with China accelerated even more. In volume and value, it certainly did. ${ }^{14}$

On the other hand, Taiwan's trade intensity index with China showed - after initial high trade intensity - a constant drop over five years of the ECFA regulations (see Table 3). A similar pattern is visible in Taiwan's market share index in trade with China (see Table 4). The results of both indices calculation show the importance of Taiwan's foreign trade, even though its share of worldwide exports has declined, and Taiwan is gradually losing competitiveness in industrial sector. ${ }^{15}$

Table 3. Taiwan's trade intensity index in trade with China

\begin{tabular}{|l|l|l|l|l|}
\hline 2010 & 2011 & 2012 & 2013 & 2014 \\
\hline 3.23 & 2.98 & 2.87 & 2.68 & 2.56 \\
\hline
\end{tabular}

Source: author's calculations.

Table 4. Taiwan's market share index in trade with China

\begin{tabular}{|l|l|l|l|l|}
\hline 2010 & 2011 & 2012 & 2013 & 2014 \\
\hline 2.71 & 2.63 & 2.41 & 2.28 & 2.21 \\
\hline
\end{tabular}

Source: author's calculations.

The alternative trade partners with the greatest potential are the countries of Southeast Asia. This direction was already treated in a strategic way by the Taipei authorities in the 1990s, without great success. It may be a viable alternative for the development of the island's economy nowadays in a situation of growing dependence on cooperation with China, gradual economic transition from industry to

${ }^{14}$ Value of Exports \& Imports by Country, Bureau of Foreign Trade, Ministry of Economic Affairs, Republic of China (Taiwan), http://cus93.trade.gov.tw/ENGLISH/FSCE/ (access: 28.11.2015).

${ }^{15}$ E. Trojnar, Tajwan. Dylematy rozwoju, Księgarnia Akademicka, Kraków 2015, p. 261-294. 
services, increased anti-Chinese social sentiments in Taiwan, and the victory of the Democratic Progressive Party (DPP) in the 2016 elections. Taiwan's fragile situation forces its authorities to expand globally. Moreover, in 2013 Taiwan signed free trade agreements (FTA) with Singapore and New Zealand. The FTA with other regional countries should help Taiwan to diminish its interdependence with China. The Southeast Asian countries have become increasingly important for China as well. Recent dynamics in trade suggest that in a few years China's trade with the European Union and the United States will be surpassed by Southeast Asia. The countries of this region remain key for China; they are located on the so called Maritime Silk Road, a Chinese international initiative proposed in 2013.

China is also an important destination for Taiwan's foreign direct investment (FDI). The mainland's young, relatively cheap, and dynamic market used to offer high revenues for Taiwanese entrepreneurs, who share with the Chinese a common cultural and linguistic heritage. Even though investing in China was banned in 1980s and later required obtaining a special approval from Taiwan's authorities, since the 1990s the lion's share of Taiwanese investments was directed to China through third markets. Today, Taiwanese FDI impacts not only China's and Taiwan's economic situation and cooperation from which they both benefit, it also created a social issue for Taiwan. Between one and three million Taiwanese living in China nowadays (or at least 1 of 23 Taiwanese) weaken Taiwan's fragile situation of interdependence, both in terms of sensitivity and vulnerability. Some of the Taiwanese constitute Taishang - a Taiwanese business community operating in China, which is regarded as a political tool in Beijing government's hands.

Recent data indicate, however, that China's share of outward Taiwanese FDI is steadily diminishing (see Table 5). Under the new DPP leadership this pattern will be politically supported. Taiwanese investors already active in Southeast Asia might benefit from government incentives helping them to expand on these markets.

Table 5. Taiwan's FDI worldwide (million US\$; \%)

\begin{tabular}{|c|c|c|c|c|c|}
\hline & 2010 & 2011 & 2012 & 2013 & 2014 \\
\hline Value of FDI in China (m US\$) & 14617 & 14376 & 12792 & 9190 & 10276 \\
\hline Value of FDI in other areas (m US\$) & 2823 & 3696 & 8098 & 5232 & 7293 \\
\hline Share of China in the Taiwan's FDI (\%) & 83.8 & 79.5 & 61.2 & 63.7 & 58.5 \\
\hline
\end{tabular}

Source: D-4 Approved Outward Investment by Area, D-6 Approved Indirect Mainland Investment, Ministry of Economic Affairs, Republic of China (Taiwan), http://www.moea.gov.tw/Mns/dos_e/content/ContentMenu. aspx?menu_id=6752 (access: 28.11.2015).

Analysis of Taiwan's interdependence with China could be completed by a brief estimation of China's sensitivity and vulnerability with Taiwan. Assuming that Taiwan is the sole partner in cross-Strait relations, trade and investments as independent variables of China's security show a completely different situation. First of all, Taiwan remains an important investor in China: cumulatively in 2014 its FDI amounted to US\$119.5 billion, a 4.3\% share (Table 6). In 2014, only FDI 
from Taiwan was estimated at US $\$ 5.18$ billion, just behind Singapore (US\$5.93 billion) and Hong Kong (US\$85.74 billion). They overtook Japanese direct investments (US $\$ 4.33$ billion), as well as those of South Korean (US\$3.97 billion), and the United States (US\$2.67 billion).

Table 6. Taiwan's investment in total FDI in China (US\$ billion; \%)

\begin{tabular}{|c|c|c|c|c|c|}
\hline & \multicolumn{1}{|c|}{2010} & \multicolumn{1}{c|}{2011} & \multicolumn{1}{c|}{2012} & \multicolumn{1}{c|}{2013} & \multicolumn{1}{c|}{2014} \\
\hline Value of investments from Taiwan & 6.701 & 6.727 & 6.183 & 5.246 & 5.150 \\
\hline Total investments in China & 105.735 & 116.011 & 111.716 & 117.586 & 119.560 \\
\hline Share of investments from Taiwan (\%) & 6.3 & 5.8 & 5.5 & 4.5 & 4.3 \\
\hline
\end{tabular}

Source: Statistics for FDI in China, years: 2010, 2011, 2012, 2013, 2014, Ministry of Commerce, Peoples Republic of China, http://english.mofcom.gov.cn/article/statistic/foreigninvestment/ (access: 28.11.2015).

In terms of trade relations, Taiwan was China's seventh largest trading partner and the fifth largest source of imports. Due to increases in both exports and imports, in 2014 the value of trade Taiwan reached US\$198.31 billion and the share $4.6 \%$ (see Table 7).

Table 7. China's trade with Taiwan (US\$ billion; \%)

\begin{tabular}{|c|c|c|c|c|c|}
\hline & 2010 & \multicolumn{1}{|c|}{2011} & 2012 & \multicolumn{1}{c|}{2013} & \multicolumn{1}{c|}{2014} \\
\hline Export to Taiwan (US\$ billion) & 29.68 & 35.11 & 36.78 & 40.64 & 46.28 \\
\hline Import from Taiwan (US\$ billion) & 115.69 & 124.91 & 132.18 & 156.64 & 152.037 \\
\hline Trade with Taiwan (US\$ billion) & 145.37 & 160.02 & 168.96 & 197.28 & 198.31 \\
\hline Share of trade with Taiwan in total trade (\%) & 4.9 & 4.4 & 4.4 & 4.7 & 4.6 \\
\hline
\end{tabular}

Source: Statistics Mainland-Taiwan Trade and Investment, years: 2010, 2011, 2012, 2013, 2014, Ministry of Commerce, Peoples Republic of China, http://english.mofcom.gov.cn/article/statistic/foreigninvestment/ (access: 28.11.2015); China Statistical Yearbook, years: 2010, 2011, 2012, 2013, 2014, National Bureau of Statistics of the People's Republic of China, http://www.stats.gov.cn/english/Statisticaldata/AnnualData/ (access: 28.11.2015).

\section{TAIWANESE PUBLIC (NON)ACCEPTANCE OF THE GROWING INTERDEPENDENCE WITH CHINA}

Seeing Taiwan's trade and investment relations with China as the only measure of Taiwan's security is undoubtedly an oversimplification. The real picture is more complex and at the same time clear when a corresponding social dimension is included. In July 2010 public survey $15.5 \%$ of the Taiwanese were very satisfied with the results of the ECFA negotiations and $45.6 \%$ somewhat satisfied. On the opposite side, $12.9 \%$ were slightly unsatisfied and $17.1 \%$ very unsatisfied; $8.9 \%$ did not know or had no opinion. ${ }^{16}$ Four years later, Taiwanese attitudes towards

${ }^{16}$ Question: "On the whole, are you satisfied or unsatisfied with the results of the ECFA negotiations?", July 2-4, 2010, number of effective samples: 1,114; Survey on Public Views on 
fostering relations with China were sharply exacerbated. In an April 2014 survey on opinions about signing the Cross-Strait Service Trade Agreement (CSSTA), only $8.8 \%$ expressed strong support and $33.7 \%$ support. Antagonists and proponents were balanced, as $20.5 \%$ opposed the agreement and $19.6 \%$ strongly opposed it, while $17.4 \%$ of respondents either did not know or had no opinion. ${ }^{17}$

Publicly demonstrated reluctance of some Taiwanese to support the KMT's policy (2008-2015) aiming to increase economic relations with China inclines to take into account the social factor of interdependence. Taiwan's citizens proved to be a visible power in democratic Taiwan during the student-led March 2014 demonstrations against the CSSTA, called the Sunflower Movement, proved to be a visible power in democratic Taiwan. The fragile cross-Strait issue once again, but in a new and emotional appeal, prevailed in Taiwan's security concerns. Dissatisfied with the government's policy, the Taiwanese proved to be a strong force stopping ratification of the CSSTA. Another social burst of discontented Taiwanese resulted in the DPP victory in the 2016 presidential and parliamentary elections. To what degree the election results change the situation of the Taiwanese living in the Mainland is a question of the flexibility of the new Taiwan government in cross-Strait relations. It is widely accepted that established and well operating channels of economic relations play a prime role and serve the purposes of both governments. The growing interdependence of Taiwan and China should therefore encourage Taiwan's government to search for new solutions to the wider participation of society in the public debate on the future paths of crossStrait relations. This situation, together with the key issue of Taiwanese national identity, its formation, and the disappearance of the Chinese one, remain a crucial factor of Taiwan's security. In 2015, almost $60 \%$ of the inhabitants of the island declared Taiwanese identity and only 3.3\% Chinese identity. It was pointed out that the inhabitants with a double identity, i.e. Taiwanese and Chinese, amounted to over $33.7 \% .^{18}$

At the same time, it is unlikely that China will change its political course towards Taiwan, which does not reinforce Taiwan's fragile security. Neither is Taiwan's newly-elected president, Tsai Ing-wen, who was quite clear about this issue even before elections, planning changes. Under new leadership, Taiwan will

the Fifth Chiang-Chen Talks Percentage Distribution for Each Question, Mainland Affairs Council, Executive Yuan, China Credit Information Service, http://www.mac.gov.tw/public/Attachment/071417492543.pdf (access: 24.11.2015).

${ }^{17}$ Question: "Do you support or not support the signing of the Trade in Services Agreement between Taiwan and the Mainland?", April 9-13, 2014, Number of effective samples: 1,104; Percentage Distribution of the Questionnaire for the Survey on the "Public's Views on Supervision of Cross-Strait Agreements", Mainland Affairs Council, Executive Yuan, Election Study Center of National Chengchi University, http://www.mac.gov.tw/public/Attachment/47316291729.pdf (access: 24.11.2015).

${ }^{18}$ Changes in the Taiwanese/Chinese Identity of Taiwanese (1992-2015, 06), Election Study Center of National Chengchi University, http://esc.nccu.edu.tw/course/news.php?Sn=166 (access: 2.02.2016). 
preserve status quo in cross-Strait relations. The Taiwanese will face a contradiction; they have elected the president and the majority of the Legislative Yuan from the Democratic Progressive Party, known from its pro-independence character. On the other hand, China's political resources are robust, especially since 2005, when the Anti-Secession Law was passed, giving Taiwan less room to manoeuvre. The new Taiwanese leadership could however find new grounds for peaceful crossStrait relations and develop alternative directions for the sake of Taiwan's security. Undoubtedly, again economic relations will be prime example of these efforts.

\section{CONCLUSION}

Nowadays, Taiwan's economic security depends heavily on China's market. Contrary to business needs and the benefits of free market regulations, fragile cross-Strait relations depend on regulated cooperation, which requires much attention to controversial issues. Needless to say, it takes more time and causes a loss of some business opportunities, but it is reasonable for the sake of Taiwan's security. The process of institutionalization of cross-Strait economic cooperation gained momentum after the victory of the KMT in 2008. Throughout the following eight years of the KMT rule between 2008-2015, cross-Strait relations advanced, creating new openings for both sides. On the other hand, at the same time the security threat from China's side did not diminish. Moreover, increasing Taiwanese economic dependence on China was considered a decisive power in cross-Strait relations. The Taiwanese understand their weak bargaining position and possible costs of further facilitation of cooperation with China, and therefore stalled their support for the KMT-led policy and negotiations. In other words, Taiwan is very fragile in relations with China, which emphasizes its urgent need to diversify economic cooperation and develop non-hostile relations with it. Due to the growing disparity of power between China and Taiwan, where China possesses more economic and political assets, Taiwan is the more sensitive and vulnerable partner. It will be costlier to Taiwan in the short and long run, if it is necessary to adopt changes. It somehow explains Taiwan's concerns on the occasion of any change in the cross-Strait relations; while it may be beneficial for Taiwan in a short run, it presupposes unknown future. The level of asymmetrical interdependence in economic relations is very high, and a radical shift in Beijing's policy towards Taiwan in this area would create costs on both sides, however they would be more harmful for Taiwan. Therefore, the realists' fear of the stronger partner in an asymmetrical interdependence resorting to force if their strategic interests collide does not sound congruent in the cross-Strait case. 


\title{
BEZPIECZEŃSTWO EKONOMICZNE TAJWANU W KONTEKŚCIE WSPÓŁZALEŻNOŚCI CHIŃSKO-TAJWAŃSKICH
}

\begin{abstract}
Abstrakt. W 2010 roku Tajwan i Chiny zawarły przełomowe w dziejach kontaktów bilateralnych porozumienie o współpracy gospodarczej. Wśród wielu konsekwencji wdrożenia jego postanowień uwagę zwraca rosnąca zależność gospodarcza Tajwanu od Chin. Bezpieczeństwo ekonomiczne Tajwanu badane przez pryzmat asymetrycznej współzależności, osadzonej w neoliberalnej teorii stosunków międzynarodowych, wskazuje nie tylko na wysoką wrażliwość Tajwanu i Chin, ale i koszty jakie partnerzy musieliby ponieść w przypadku zmiany dotychczasowej polityki.
\end{abstract}

Słowa kluczowe: bezpieczeństwo ekonomiczne, współzależność, Tajwan, Chiny, stosunki chińsko-tajwańskie 